\title{
School Management's Perception of Corporate Social Responsibility (CSR): An Exploratory Study
}

\author{
Chinmaya Prakash ${ }^{1}$ (D) and Shubha Chandra ${ }^{2}$ \\ ${ }^{1,2}$ Department of Management and Commerce, Garden City University, Bangalore-560049, India \\ ${ }^{1}$ chinmaya171384@gcu.ac.in (Corresponding Author) \\ ${ }^{2}$ shubha.chandra@gardencity.university
}

\section{ARTICLE INFORMATION}

Received: August 05, 2020

Revised: September 09, 2020

Accepted: September 21, 2020

Published Online: October 21, 2020

\section{Keywords:}

School management as stakeholders, Corporate Social Responsibility, CSR in School, SDMC, Impact of CSR

\begin{abstract}
Background: In recent years, the importance of school as a stake-holder in CSR activities is gaining recognition. Companies channel financial and human resources into developing schools. School Development and Monitoring Committee (SDMC) plays an important part in the management of Primary schools in Karnataka and as such should have a role in CSR activities.

Purpose: This exploratory study attempted to answer the following questions- (1) How aware are SDMC members of CSR and its role in schools (2) what is their perception of CSR in their schools? (3) Do rural and urban SDMC members differ in their perception of CSR

Methods: Sample consisted of SDMC members from 50 rural and 50 urban Government run primary schools in Bangalore Educational districts. 100 SDMC members, one from each school, were interviewed using a semi structured information schedule developed for this study

Results: Management is not very clear about the nature of CSR support . However, $75 \%$ of them perceive CSR as beneficial to their schools. Rural subjects have a more favourable perception of CSR impact and they differ significantly from urban counterparts in rating ' how CSR has benefited students' $(\mathrm{t}=2.052)$.

Conclusions: SDMC members do not clearly distinguish between support provided under CSR and support received from other sources. Overall, CSR is seen as beneficial to school by supplementing government support and helping the management. Rural schools seem to benefit more from CSR support. Though SDMC is supposed to monitor the developmental activities of the school, they are not often consulted by companies about the requirements for the school. Involving SDMC in planning, executing and monitoring would enhance the efficacy of CSR programmes.
\end{abstract}

\section{Introduction}

Since Independence, India is moving toward the goal of Universal Elementary Education (UEE). The country has made significant strides in this direction. The current scheme for Universalization of Education for All is the Sarva Shiksha Abhiyan which is one of the largest education initiatives in the world (GOI, 2011). As an outcome of such efforts, the number of students in the age group 6-14 years who are not enrolled in school had come down to $2.8 \%$ in the academic year 2018 (ASER, 2018). In India, the state provides free basic education as a fundamental right of children. $80 \%$ of all recognized schools at the elementary stage are government run or supported, making it the largest provider of education in the country.

However, providing quality education to the masses in a country so ridden with problems is not an easy job. At the same time, primary education is a basic necessity that cannot be compromised as it is the foundation for development of future citizens. Hence, the state needs the cooperation and support of civil society and organizations to ensure development of schools. Since Corporate social responsibility (CSR) became mandatory for companies, education sector is being supported by companies in several ways. CSR is defined as 'the obligations of business to pursue those policies, to make those decisions or to follow those lines of action which are desirable in terms of the objectives and values of our society' (Bowen, 1953). The provision regarding CSR in the New Companies Act 2013 has brought within its ambit all the companies with at least Rs 5-crore net profit or Rs 1,000-crore turnover or Rs 500-crore net worth making its mandatory for them to spend 2 
per cent of the three years' average net profit on CSR activities.

Simply put, the concept of CSR refers to 'giving back to the society' and this is not a new concept for India. Donating a part of one's earning is considered a duty by most religions. Supporting social causes has been a part of the value system in Indian tradition (Hemlata, 2010). Tracing the history of CSR in India, Krisnhamacharyulu (1981) refers to a verse from the Ishopanishad to emphasize the point that charity and philanthropy had been a part of Indian culture from the Vedic times. In modern times, companies are contributing to social developmental activities as a part of their philanthropic activity. Most Indian companies prefer investing in education as they consider education an important tool for social development. Chauhan and Dawra (2017) cite the report of Global CSR Summit that providing infrastructure support is the most common activity in the education domain undertaken by approximately $88 \%$ (44 out of total of 50 companies focusing on education thematic area) of the companies.

Any education system will have several stakeholders. Stakeholders include persons, neighbourhoods, institutions, groups and organizations and environment that could potentially influence the school. According to Edward Freeman's (1984) stakeholder theory, all those who influence or are influenced by a corporation hold a right in participating and directing it. As such, ideally any CSR work in school should involve all such stakeholders. Who are all the stakeholders in a school system? The learning environment in the school may be impacted by several sources. The figure given below shows some such players who are important for the school.

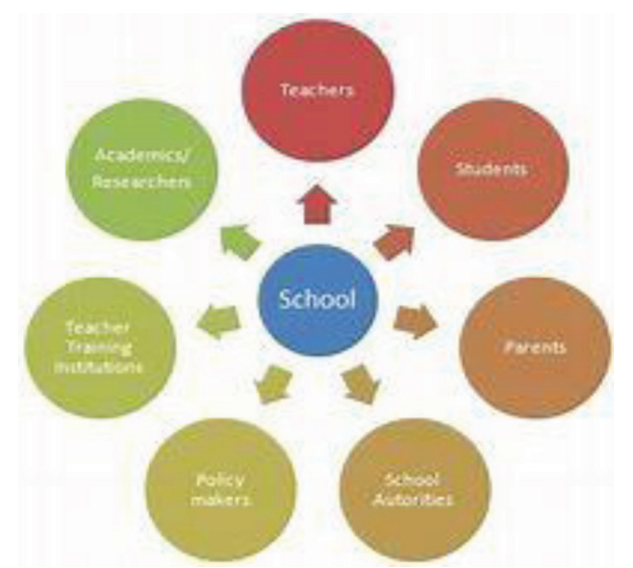

Figure 1: Some of the major stakeholders in a school system.
It is well understood that stakeholders in the school should be part of all developmental activities. However, as Ismail et al., (2014) point out, school especially teachers as stakeholders in CSR activities is not seriously taken into consideration. It is also important for companies to consider community expectations about CSR services. Parekh et al. (2015) surveyed the performance of 100 listed companies. They found that many companies responded to the needs of community as an important stakeholder and supported local schools. But poor learning outcomes that are reported in spite of heavy investment may be due to lack of strategic thinking and absence of a balanced approach by companies. Probably involving stakeholders at all levels of planning and executing programs is lacking.

School stakeholders have an interest in the development of the school and as such should be part of any CSR initiatives. One important stakeholder in the school system is the School Management. Variously known as school committee, management committee and School Development and monitoring committee, such committees are constituted to improve quality of government schools. Such committees will be effective only when they are aware of their roles, responsibilities and are made active participants in developmental programs. It is also important to know how stakeholders perceive the CSR support and whether there is a mismatch between expectations of school management and CSR programs that are implemented. There is little research available in this area (Ismail et al., 2014). This study attempts to look at CSR from the perspective of one of the stakeholders, namely the SDMC.

\section{Review of Related Literature}

The review briefly covers three areas -brief review of role of school management in the school system; functioning of SDMCs as an important stakeholder; and role of CSR in schools. Community based school management is becoming a norm as globally, there is an increasing decentralization of school administration. De Grauwe (2005) considers school-based management as a shortcut to more efficient management of school and to improve quality of education. This is specially so in developing countries. This Right To Education Act of 2009, which ensures free and compulsory 
education to children of the country, enumerates the role of the School Management Committee (SMC) as an important component of school education. Aikara (2011) studied the effect of decentralization and community participation in Kerala schools. Rao (2009) reports the effect of lack of community participation on Sarva Shiksha Abhiyan. There have been several studies on the role of village education committee (Shankar, 2008), community participation and involvement (Vaijayanti, 2005). Similar studies have been reported from Rajasthan (Ramachandran, 2001), Zhang district ( Pervaiz et al., 2016), and from West Bengal (Wankhede and Sengupta, 2005).

In Karnataka, SDMC is an important part of the school system. For effective implementation of Sarva Shiksha Abhiyan, community ownership and involvement are essential. For this purpose, Government have set up SDMC since 2001. This is a school level committee for monitoring development of the school. Basically, SDMC is a subcommittee of the Civic Amenities committee of Gram Panchayat. Members of SDMC will be parents of students of the school, Head of the school, Anganawadi workers, health workers, one elected member of the local body, one teacher and one student. It is supposed to meet every month to discuss the progress of the school. The SDMC has been given necessary powers and functions for ensuring that schools are managed better (http://schooleducation.kar.nic.in/pdffiles/SDMC_ ConsolidatedLetters.pdf).

The SDMC is the designated local authority which implements the provisions of the Act (2010) at the school level. The SDMC shall ensure that every child in the jurisdiction of the respective school shall get enrolled in the school, attend school regularly and get quality education. The SDMC shall also ensure that there are no dropouts /out-of-school children in its jurisdiction. The head teacher of the school shall periodically bring to the notice of the SDMC all such lapses and violations of the Act and Rules. Since SDMC members are major stakeholders in the development of the school, their involvement and perception of CSR programs is an important factor to be considered (Bandhyopadhyay \& Dey, 2011). This study examines to what extent SDMC members as stakeholders are involved in CSR programs of their schools.

There have been several studies evaluating the performance of school management committees
(Rout, 2014). Nadarasa and Thuraisingam (2014) consider School administration an important part of education system. Effective school leader can change the face of a school and contribute to student growth. Thapa (2012) from her study concludes that SMCs are not functional at all. SMC has become more of a formality than practicality and it does exist on paper but in reality, it is nearly non-existent. She says neither local community nor SMC members themselves are aware of their roles and responsibilities. Kumar (2016) in his study carried out in Himachal Pradesh found that most of the SMC members were not even aware of purpose behind formation of SMC. Their role in the preparation of School Development Plan was negligible and very few of the SMC members knew about their role in the making such plans. Paucity of funds, lack of support from administrative authorities were frustrating them. SMC members from agrarian background found it difficult to spare time for meetings and other related activities nor did they have academic background to contribute to committees.

As opposed to such studies there are positive reports of the work of school committees. Van Wyk and Marumoloa (2012) are all praise for school-based management. They found in South African situation, schools an especially important policy making and implementing body. Similarly, Meher and Patel (2018) consider the work of school management committee (SMC) praise-worthy. In Jharsuguda district, they found SMC members taking steps to enroll, retain and promote achievement of children. SMC was formulating and executing school development plans efficiently in the district. A report by Niranjanaradhya (2014) shows that the SDMC appears to have played a significant role towards access, enrolment, retention and school monitoring. Based on his findings, recommendations are made toward policy changes, capacity building, linkage, accountability and transparency.

A study was conducted by CEIAR (2019), Tata Institute of Social Sciences, Mumbai in four states, namely Odisha, Bihar, Rajasthan, and Telangana. Data about SMC was collected from all the stakeholders by using survey method. The major findings of the study revealed that SMCs across the states differed in terms of constitution, the process of formation and functioning depending on the rules and norms of the State as well as the existing social structure within and around the 
schools of the State. This resulted in inconsistencies in the experiences, skills, understanding and expertise required by SMC members across various schools through the four states. In general, it was observed that almost all the SMCs had inadequate funds to carry on the roles and responsibilities assigned to them to function in a prescribed manner.

Bandyopadhyay and Dey (2011) prepared a policy brief for CREATE from 88 schools in three clusters in Madhya Pradesh and Chhattisgarh. They report mis-judgements by SMCs as they are not clearly aware of school situation and mismatch between their perceptions and actual school situations. This calls for increased training and involvement of members to discharge their roles as SMC members. In the paper on 'Stakeholder involvement in Schools in $21^{\text {st }}$ Century for Academic Excellence' Gichohi (2015), reports that in spite government efforts, there is deterioration of performance of primary schools mainly because lack of participation by stakeholders. The study of 53 schools found that there is a need to sensitize stakeholders to improve the learning environment as Stakeholder involvement in schools is responsible for performance of schools. This study recommends that sensitizing workshops should be held for all stakeholders aimed at building team work for effective management of schools.

Coming to the role of CSR in developmental activities, Ismail (2009) states that the very logic of CSR is to make an impact in community socially, environmentally and economically. There is a rapid spread of CSR programs with community involvement and school as one of the stakeholders because school is a community constituent. School as a stakeholder shows the significance of CSR as a program in developing school through which various financial and human resources are channeled. The way in which the stakeholders perform their tasks in CSR programs depends on their perception. Hence, community expectations regarding CSR program are important (Ismail et al., 2014).

Speaking of CSR, Cushla and Hay (2009) state that school and industry partnership can provide an important impetus to development of education. Sen Gupta and Wadera (2019) examined the importance of awareness and understanding of CSR on consumers. However, not all stakeholders have a clear understanding of the role of CSR. Even students of higher education have been found to have poor awareness of CSR (Girija and Shaktivel, 2015). In a study for Samhita Social Ventures by Parekh and Prakash (2015) it was found that while it is encouraging to have the large scale of corporate participation, their efforts are skewed thereby creating an imbalance in the sector. For instance, only 29 per cent of the companies support remedial education, and a dismal 9 per cent support changes such as curriculum enhancement and formative assessments. This study shows that companies may be concentrating their CSR efforts on infrastructure at the cost of other systemic issues that need reform.

In a study of impact of CSR on Human resources in schools, Prakash and Chandra (2020) found that 23\% of teachers interviewed were not aware of CSR though their school was receiving CSR support. 47\% said CSR partners interacted with them only 'sometimes'. 55\% were happy with the support provided and $29 \%$ were unsure. From the above studies, it appears that CSR may not be involving all the stakeholders in its work.

\section{Present Study}

The need for the present study is highlighted by the above review. There are evaluative studies of SMCs and of CSR. But not much information is available as to how stakeholders perceive CSR in their schools. It is clear that SMC is an important stakeholder and CSR is investing in schools in a big way. But the question is does school management as major stakeholders really understand the nature of CSR activities and how do they perceive its impact on the school. Though there are many evaluative studies of SMCs, how CSR is perceived by them is not researched. This exploratory study was carried out to find out the perception of CSR by school management, more specifically, the SDMC.

\subsection{Objectives of the Study}

The main purpose was to examine the understanding of CSR by the school management and the views of the members as to how their schools have benefitted by CSR support. SDMC members as major stakeholders were taken up to study as they are supposed to be in charge of all developmental activities of the school.

Since this was mainly exploratory, no specific hypotheses were set up. However, three main questions were considered. 1) How aware are SDMC members of 
CSR and its role in schools 2). What is their perception of CSR in their schools? 3) Do rural and urban SDMC members differ in their perception of CSR?

\subsection{Sample}

For this study, 50 schools in Bangalore urban and 50 schools in Bangalore rural educational districts were selected. These were Government Primary and Higher Primary schools which were receiving some type of CSR support. From each school one SDMC member was selected for the study. It was a convenient and purposive sampling. The criteria for selection of the sample was that the school selected was receiving some type of CSR support for at least two years at the time of the study and that member responding had been associated with the school for at least two years. This was to ensure that members were not new and unfamiliar with the school situation. Table 1 gives details of the sample

Table 1: Gender and location-wise distribution of the sample.

\begin{tabular}{|l|l|l|l|}
\hline SDMC members & Male & Female & Total \\
\hline Rural & 24 & 26 & 50 \\
\hline Urban & 12 & 38 & 50 \\
\hline Total & 36 & 64 & 100 \\
\hline
\end{tabular}

There were more female members in the sample. There was more so in urban areas. Government also encourages more participation by women members in school management.

\subsection{Method of Data Collection}

In order to elicit information, a semi structured interview schedule was prepared. This was based on extensive literature review of CSR and school management studies and a pilot study. First part of the schedule dealt with demographic details, and background information about the school. Second part elicited CSR related information about following areas:

a) Perceived benefit to school- such as improvement in infrastructure, cleaner school premises, school safer, improvement in enrolment, attendance and examination results.

b) Perceived benefit to students, - such as financial help to students, improvement in health, nutrition, increased opportunities to participate in co-curriculars, skill development, values and improved attendance and regard for the school. c) Perceived benefit to teachers - such as improvement in pay, opportunities to improve teaching skills, improved relationship with students, parents, colleagues and management.

d) Benefits to management- such as enhancing the ability of the management to improve school, recruit more teachers, get trained in management skills and sensitize community.

\subsection{Procedure}

Data collection had to go through a series of procedures and paperwork. First, permission had to be obtained from the departments of education responsible for the respective areas. Next, was to get introduced and establish contact with the NGO that would be working with the school. Most companies channel their support through a partner organization. Through the organization, the school management had to be approached. Date and time had to be negotiated with SDMC members. Once the appointment was made, the task was to convince the member that the study was purely for academic purpose and confidentiality would be maintained. Each person was interviewed and their responses to the schedule were recorded. This process took nearly six months as schools were dispersed all over the educational district and subjects were not readily available.

\subsection{Results}

Data thus collected were analyzed and the results are given in tables below. Most of the schools sampled were receiving help from more than one source. Usually support was given annually, and some schools got occasional and irregular help from companies. Mean scores were worked out for age of the respondents as well as rating scales and are given in Table 2.

Table 2: Mean age and mean ratings on CSR variables.

\begin{tabular}{|l|l|l|l|l|l|}
\hline & & Rural & $\mathbf{N = 5 0}$ & Urban & $\mathbf{N}=\mathbf{5 0}$ \\
\hline & Mean & S.D. & Mean & S.D & T \\
\hline Age in years & 38.98 & 7.18 & 37.8 & 8.96 & 0.726 N.S \\
\hline $\begin{array}{l}\text { CSR Benefit to } \\
\text { students }\end{array}$ & 3.00 & 0.51 & 2.82 & 0.35 & $2.052^{*}$ \\
\hline $\begin{array}{l}\text { CSR Benefit to } \\
\text { school }\end{array}$ & 2.32 & 0.37 & 2.06 & 1.23 & 1.40 NS \\
\hline $\begin{array}{l}\text { CSR Benefit to } \\
\text { Teachers }\end{array}$ & 2.64 & 0.48 & 2.62 & 0.55 & 0.193 NS \\
\hline $\begin{array}{l}\text { CSR Benefit to } \\
\text { Management }\end{array}$ & 2.42 & 0.68 & 2.24 & 0.86 & NS \\
\hline
\end{tabular}

${ }^{*} \mathrm{p}<.05$ N.S. Not significant 
Rural SDMC members have rated CSR significantly high on the variable 'Benefit to students' from CSR support to school. In general, Rural school have a more positive attitude toward CSR on all the variables. Most of the members rated satisfaction with CSR as OK to highly satisfactory. Dissatisfaction was expressed by $4 \%$ in CSR benefit to students, $19 \%$ in benefit to school, $5 \%$ in benefit to teachers and $15 \%$ in benefit to management. In what way has CSR helped management in improving their management efficacy was the next question. Results are given below.

Table 3: Impact of CSR on Management as reported by SDMC (Percentages).

\begin{tabular}{|l|l|l|}
\hline $\begin{array}{l}\text { SI. } \\
\text { No }\end{array}$ & Impact of CSR & SDMC \\
\hline 1 & Able to improve school & $72 \%$ \\
\hline 2 & Able to recruit more teachers & $22 \%$ \\
\hline 3 & Got trained to manage school & $43 \%$ \\
\hline 4 & Better able to sensitize community about school & $77 \%$ \\
\hline
\end{tabular}

On the whole SDMC feel that CSR support to school has created a better awareness in the community about the school. For management school building and its improvement is important because they believe that attractive school building will attract more students. Most of them express gratitude that school has improved in many ways due to external support. This has created awareness in community about school and its function. Also, SDMC members are drawn from local community which creates local involvement in schools. Open ended questions had been asked about expectations of members from CSR. The results are given below.

Table 4: Expectations of SDMC from CSR.

\begin{tabular}{|l|l|l|l|}
\hline $\begin{array}{l}\text { SI. } \\
\text { NO }\end{array}$ & Expectation & $\begin{array}{l}\text { Garret } \\
\text { Value (\%) }\end{array}$ & Ranking \\
\hline 1 & Improve Infrastructure & 61.6 & I \\
\hline 2 & Provide furniture/ materials & 58.0 & IV \\
\hline 3 & LTM requirements & 60.3 & III \\
\hline 4 & Skill development & 61.3 & II \\
\hline 5 & Health camps for students & 57.1 & V \\
\hline 6 & Teacher empowerment & 50.4 & VI \\
\hline 7 & Reform management & 46.5 & VIII \\
\hline 8 & $\begin{array}{l}\text { Parental guidance, } \\
\text { Sensitization }\end{array}$ & 46.4 & IX \\
\hline 9 & Community reach out & 50.1 & VII \\
\hline
\end{tabular}

Infrastructure was a major issue for most of the schools. Old buildings needing repairs, inadequate number of class rooms, absence of compound wall, lack of proper toilet facilities were common complaints. Skill development of students in terms of improving spoken English, help with Math's and Science, vocational skills, computer skills and personality development were also rated as priorities. Management reform and parental guidance were ranked lower than other issues.

\section{Discussion}

Since this study was exploratory in nature, it did not start with any set hypotheses. However, awareness and perception of CSR impact were the major concerns. SDMC members came from varied background. Literacy level varied as most were semi-literate and a few were reasonably well educated. In most cases they were parents of the students of the school. In a few cases the alumnus of the same school had become SDMC members. Management committees are usually very heterogenous as it is made up of members from different strata and categories of society. As per government order, representation has to be given to women, SC/ST, Gram panchayat, Anganwadi workers etc. As such their educational and social status and cultural background varied. Most of them were in their late thirties. There was no significant difference in the mean age of rural and urban SDMC members $(\mathrm{t}=$.726).

With regard to CSR support, $34.5 \%$ of the schools were getting support from one company whereas $64.5 \%$ of schools got help form more than one organization. Most frequent type of support given was on yearly basis (39\%), followed by occasional help (32\%). In many cases members mixed up help given by donors and charitable organizations with those received by a company under CSR. Many schools received occasional help from old students, local leaders and religious organizations. The type of support varied from material support such as renovation of school building, providing furniture to non-material such as conducting quiz programs and medical camps for children.

SDMC members were aware that their school was receiving support from different sources. This was not necessarily CSR support but could be a combination of sources. SDMC members would enumerate the 
help received for the school but were not clear about the nature of the source. Schools received help from charitable organizations, local leaders and old students. Some political leaders and heads of community organizations would distribute sweets or books to students on certain occasions such as birthdays. Old students would also help by providing furniture etc. SDMC members did not make a distinction between such 'donations' and the CSR support. They had no clear idea of what is CSR and how and why companies are carrying out CSR.

These finding is in close agreement with other studies on SDMC which indicate a general lack of awareness among SMCs about school issues (Bandhopadyay \& Dey, 2011, Thapa, 2012). Lack of awareness about CSR is reported in many other stakeholders (Sen Gupta \& Wadera, 2019), in higher education students (Girija \& Sakthivel, 2015) and in teachers (Prakash \& Chandra, 2020). In this context, Govinda and Bandyopadhyay (2010) argue for increasing awareness among local governing agencies about local educational problems and their effective participation in day today functioning of schools as well as in decision making processes. Similarly, data from CREATE (2011) shows that though almost all government schools have SMCs, there is a big question as to whether they have knowledge of key issues affecting the school. This clearly calls for sensitizing management about role and importance of CSR.

Most subjects are satisfied with support they receive. Rural students benefitted more from CSR initiatives than urban according to ratings given. Uniforms, shoes, books and such other materials are distributed by organizations to students. In some schools, children get milk and biscuits or breakfast from organizations. For some children, the mid-day meal is the only proper meal they get in a day. 37\% rated CSR as 'useful' and $44 \%$ as 'useful' and only $19 \%$ as 'not useful' to their schools. In terms of benefits to management, only $13 \%$ did not find CSR useful while the rest rated it as average (44\%) to useful (43\%). Overall CSR is seen as beneficial to school by supplementing government support and helping the management. There are rural urban differences in ratings given only on perceived benefits to students.

Poor infrastructure is a common problem in most government run schools. Old buildings, one room school, class rooms needing repairs, leaky roofs, non- functional toilets are common scenes. Some schools do not have a compound wall or fence around the school and as a result stray cattle and dogs haunt the premises. There are no specified cooking or food serving area in many places. Most schools have one room that gets converted into a kitchen on rainy days. The single classroom becomes the dining area for children. Schools are asked to teach Yoga, but there is no proper field or covered area where children can carry on activities during inclement weather. Hence, infrastructure is on the top of their wish list.

Members feel that extra value addition to students in terms of special coaching in English, computer use, vocational skills and personality development are needed for their school to compete with private schools.

Valuable information emerged more through informal dialogue with staff and members. In most schools, in true spirit of Indian hospitality, staff would invite the researcher to share mid-day meal with students and staff. Sharing the meal (usually Ragi ball or rice with accompanying gravy of some sort) seemed to remove invisible barriers. Staff would become communicative and share their problems, hopes and disappointments. Based on both formal and informal data, following points emerged.

Awareness of CSR: SDMC members 'knew' about CSR but vaguely. They did not have any clear idea of the philosophy guiding CSR work of companies. In some cases, the identity of the company supporting the school was not known to them. Usually they would say '..x or y 'samsthe' is helping them. 'Samsthe' (organization) is the term they used to refer to the NGO working with them. This is not surprising as Abdul Rashid and Ibrahim (2002) report that even managers in companies do not fully comprehend the importance of CSR programs. Girija and Shaktivel (2014) also found poor awareness of CSR even among higher education students.

Perception of CSR Support: In general, there was a positive attitude toward CSR work. Most members were grateful for any type of support as the Government aid was sometimes inadequate and irregular. A member said "parents of most students are daily wage earners. If the family is even slightly better economically, they will send children to private schools. Our students are poor, so anything they get.. bags, shoes, food supplement.... 
is welcome". So most agreed that CSR had really done 'some good' to the school.

Dissatisfaction with CSR: Under condition of strict anonymity, some members expressed their unhappiness with CSR work. Major complaints were inadequacy and lack of continuity of support. A member remarked, "Company $\mathrm{x}$ built this small class room and painted their name on the wall 8 years back. We haven't seen them since then". Adopting the school is better for its development.

Involvement with CSR: It was clear that SDMC members as major stakeholders were nowhere in the picture while planning or executing the programs. Most said they had not met the company representatives at all. A member made this comment "the old man selling tea in front of our school has more information about this school than these 'officials". Their interaction was mainly with NGO partners. Almost all the members interviewed said they had not been consulted about requirements for the school.

Loss of Autonomy: There were some fortunate schools which had been adopted by Corporate giants. One such 'lucky' adopted rural school near Devanahalli had swanky new building, fully equipped science and computer lab. It could compete with any urban up-market private school. The complaint from many school Managements of these adopted schools was "they have taken over our school, we are under their thumb". Some Heads of such schools were reluctant even to participate in the study without permission from the companies supporting them.

Suggestions for Improvement: While there was a long list of shortcomings in the schools and what were needed, some suggestions to improve CSR work also emerged. There were only 5 or 6 highly knowledgeable and articulate members out of the 100 interviewed who gave valuable insights into the working of CSR. One member said, "why can't companies work directly with schools. $75 \%$ of the money they earmark goes toward the salary of the staff of the NGO and their operational expenses. School gets only 25\%". Another remarked that companies usually restrict their work to their own locality or limited area. He pointed out 'school $\mathrm{x}$ is getting surplus funds from three companies. Our school is just $2 \mathrm{~km}$ down the road and we do not get any help from any company. We do not have even basic facilities. Companies should go by needs of the school not by locality". Several members expressed the view that regular visits from company representative and interaction with management members is the need of the hour.

\section{Conclusion}

With reference to research questions that were raised at the beginning of this study, the following conclusions are drawn. 1) SDMC members did not have a clear idea of CSR and its role. 2) Generally, CSR is perceived as beneficial to school by SDMC members. 3) There are rural urban differences only in how CSR is considered beneficial to students, with rural SDMC members having a more favourable view.

In conclusion, school management is an important stakeholder in CSR activities. However, this exploratory study shows that SDMC members are not fully aware of the nature of CSR activities in their schools. There is a positive perception of CSR, though members wish such support would be regular and continuous. Infrastructure development and support for developing skills in students are considered as priorities. Most members do not meet the representatives of the company or its NGO partners regularly. It is clear from this study that Companies should take stakeholders into confidence and involve them in all stages of their work to have greater impact on the development of schools. As recommended by many other studies, sensitization of stakeholders is important so that their involvement in CSR programs is more effective.

\section{Acknowledgements}

I thank the management of the schools, subjects and the 19 CSR partners for their assistance and cooperation for collecting data for this study.

\section{Authorship Contribution}

First author- data collection and reporting. Second author-guidance and review of the paper.

\section{References}

Abdul, Z., \& Ibrahim, S. (2002). Executive and management attitudes towards corporate social resp responsibility in Malaysia. Corporate Governance, 2(4),10-16. https://doi.org/10.1108/14720700210447641 
Aikara, J. (2011). Decentralisation of Elementary Education and Community Participation in Kerala. Rajgiri Journal of Social Development, 2(2),161-194.

ASER (2018). Annual Status of Education (Rural) Report 2016. ASER, Retrieved from

https://www.asercentre.org/p/289.html

Bandyopadhyay, M., and Dey, M. (2011). Effective School Management Committees. Create India Policy Brief 4. Retrieved from http://www.create-rpc.org/pdf documents/India_Policy_Brief_4.pdf

Bowen, H. (1953). Social Responsibilities of the Businessman. New York: Harper.

CEIAR (2019). State of School Management Committees. A Study of SMCs in Four States of India. Centre for Education, Innovation and Action Research, Tata Institute of Social Sciences, Mumbai. Retrieved from https://tiss.edu/uploads/files/SMC_september_ Web_2019_compressed.pdf

Chauhan, K.K., \& Dawra, S. ( 2017) Corporate Social Responsibility (CSR) in India - Evolution and Challenges (From Ancient Period to Present Age). International Journal of Applied Business and Economic Research, 15(22(Part-2)), 23-36.

Cushla, K., \& Hay, S. (2009). Industry school partnerships: Reconstituting spaces of educational governance. Globalisation, Societies and Education, 7(2), 203-216. https://doi.org/10.1080/14767720902908109

De Grauwe, A. (2005). Improving the Quality of Education through School-Based Management: Learning from International Experiences. International Review of Education, 51, 269-287. https://doi.org/10.1007/s11159-005-7733-1

Freeman, R.E. (1984). Strategic management: A stakeholder approach. Boston: Pitman Press.

Gichohi, G.W. (2015). Stakeholder involvement in Schools in 21st Century for Academic Excellence. International Journal of Education and Research, 3(2), 13-22.

Girija, K., \& Sakthivel, P. (2015). CSR awareness among Students of Higher Education in Namakkal District. International Research Journal of business management, 8(2), 3-9.

Goel, M., \& Ramanathan, P.E. (2014). Business Ethics and Corporate Social Responsibility - Is there a dividing line? Procedia Economics and Finance, 11(4), 49-59. https://doi.org/10.1016/S2212-5671(14)00175-0

Government of India (2011). Sarva Shiksha Abhiyan, Framework for Implementation, Department of School Education and Literacy. MHRD, New Delhi. http://samagra.mhrd.gov.in/docs/Framework_ IISE\%20_F.pdf
Govinda, R., \& Bandyopadhyay, M. (2010). Changing Framework of Local governance and Community Participation in Elementary Education in India. CREATE Pathways to Access Research Monograph No.35, New Delhi/Brighton: NUEPA and University of Sussex.

Hemlata, M.P.N. (2010). Corporate Governance Vis-aVis Various Stakeholders in the Company, PhD. dissertation, Department of Law, University of Mumbai, India.

Ismail, M. (2009). Corporate social responsibility and its role in community development: An international perspective. The Journal of International Social Research, 2(9), 199-209.

Ismail, M., Johar, R.F.A., Rasdi, R.M., \& Alias, S.N. (2014). School as Stakeholder of Corporate Social Responsibility Program: Teacher's Perspective on Outcome in School Development. Asia-Pacific Educational research, 23(2), 321-331. https://doi.org/10.1007/s40299-013-0107-8

Krishnamacharyulu, C.S.G. (1981). Corporate Social Responsiveness in India, $\mathrm{PhD}$. dissertation, Department of Commerce, Nagarjuna University, India.

Kumar, S. (2016). Roles and functions of school management committees (SMCS) of Government middle schools in district Kullu of Himachal Pradesh: A case study. Scholarly research journal for Humanity science \& English language, 3(17), 3876-3886.

Meher, V. \& Patel, I. (2018). Functioning of School Management Committee at Elementary Level. International journal of recent science research, 9(5), 26954-26958.

Nadarasa, T. \& Thuaisingam, R. ( 2014). The influence of Principal's leadership styles on school teachers' job satisfaction- Study of secondary school in Jaffna District. International Journal of Scientific and Research Publications, 4(1), 1-7

Niranjanaradhya, V.P. (2014). Community Participation and Institutional Experiences in School Education: School Development and Monitoring Committees in Karnataka. New Delhi, Oxfam, India. Retrieved from https://www.oxfamindia.org/sites/default/ files/2018-10/wp-community-participation-andinstitutional-experience-in-school-education_0_0.pdf

Parekh, A., \& Prakash, P. (2015, March 27). Why companies prefer CSR in education. The Hindu. Retrieved from https://www.thehindubusinessline.com/opinion/whycompanies-prefer-csr-in-education/article22515117. ece 
Parvaiz, R.K., Yousuf, I., Parveen, Q., Kanwal, W., \& Tayyab, M. (2016). Impact of school management committee on school management at elementary level in district Jhang. Science International, 28(3), 3115-3118

Prakash, C. \& Chandra, S. (2019). Human resources in schools: How can CSR initiatives improve them. In Vedava, P.; Muniraju, Y., Ishwara, P., \& Parameshwara (Eds) Business trends. Issues and Implications. New Delhi. (pp. 57-62) Excel India Publishers.

Ramachandran, V. (2001). Community Participation in Primary Education: Innovations in Rajasthan. Economic Political Weekly, 36(25), 2244-2250.

Rao, V.S. (2009). Lack of Community Participation in Elementary Education in the Sarva Shiksha Abhiyan: A Case study. Economic and Political Weekly, 44(8), 6164.

Rout, S.K. (2014). Functioning of School Management Committee in Rural Elementary School: A Case Study. Issues and Ideas in Education, 2(2), 247-254. https://doi.org/10.15415/iie.2014.22018

Shankar, G.K. (2008). Community Involvement in Sarva Shiksha Abhiyan: An assessment of the Village Education Committees in India. Madhya Pradesh Journal of Social sciences, 13(1), 75-88.
Sen Gupta, S., \& Wadera, D. (2019) Awareness and understanding of CSR among Indian consumers. International Journal of Research and Analytical Reviews, 6(2), 570-587.

Thapa, S. (2012) How functional are School Management Committees in the present context? Working Paper No. 271. Summer Research Internship Programme. Centre for Civil Society. 1-13.

Vaijayanti K.(2005). Involving the Community in Elementary Education: Role of School Development and Monitoring Committee. Policy Planning Unit, Azim Premji Foundation, Bangalore.

Van Wyk, C., \& Marumoloa, M. (2012). The Role and Functioning of School Management Teams in Policy Formulation and Implementation at School Level. Journal of Social Sciences, 32(1), 101-110. https://doi.org/10.1080/09718923.2012.11893056

Wankhede, G.G., \& Sengupta, A. (2005). Village Education Committees in West Bengal, India: Planned Vision and Beyond. International Journal of Educational Development, 25(5), 569-579. https://doi.org/10.1016/j.ijedudev.2005.03.005

\section{旬 CHITKARA}

\section{Issues and Ideas in Education}

Chitkara University, Saraswati Kendra, SCO 160-161, Sector 9-C, Chandigarh, 160009, India

Copyright: [C 2020 Chinmaya Prakash and Shubha Chandra] This is an Open Access article published in Issues and Ideas in Education (Issues Ideas Educ.) by Chitkara University Publications. It is published with a Creative Commons Attribution- CC-BY 4.0 International License. This license permits unrestricted use, distribution, and reproduction in any medium, provided the original author and source are credited. 